\title{
Geophysical Investigation Using Time Domain Electromagnetic Method (TDEM) at Wadi Deir Al-Kahaf Area/Jordan for Groundwater Artificial Recharge Purposes
}

\author{
Hani Al-Amoush1*, Eid Al-Tarazi2, Jafar Abu Rajab2', Younis Al-Dwyeek3 \\ Mohammed Al-Atrash ${ }^{4}$, Ahmed Shudiefat ${ }^{5}$ \\ ${ }^{1}$ Institute of Earth and Environmental Sciences, Al al-Bayt University, Mafraq, Jordan \\ ${ }^{2}$ Faculty of Natural Resources, Hashemite University, Zarqa, Jordan \\ ${ }^{3}$ Orient Engineering Consultancy, Amman, Jordan \\ ${ }^{4}$ Ministry of Water and Irrigation, Amman, Jordan \\ ${ }^{5}$ Al al-Bayt University, Mafraq, Jordan \\ Email: $\underline{\text { hani1@aabu.edu.jo }}$
}

Received 18 January 2015; accepted 2 February 2015; published 6 February 2015

Copyright (C) 2015 by authors and Scientific Research Publishing Inc.

This work is licensed under the Creative Commons Attribution International License (CC BY).

http://creativecommons.org/licenses/by/4.0/

c) (i) Open Access

\begin{abstract}
In this study, Ten Time Domain Electromagnetic (TDEM) measuring points have been conducted at four pre-selected sites along Wadi Deir Al-Kahaf in order to investigate the potential of the near subsurface deposits and aquifer for groundwater artificial recharge applications. The surveyed results suggest well resolved geological layers such as alluvial mudflat, basalt layers and their saturation states. In addition a hydrogeophysical cross section along the studied sites was constructed which permits to locate the lateral variations in rock properties due to water saturation and or facies changes. The saturated thickness of the Upper Aquifer System in the study area was found to be changed from $5 \mathrm{~m}$ near TEM 1 to about $120 \mathrm{~m}$ near TEM 4 in thickness. The Abed Basalt Aquifer (AOB) has an average saturation thickness of about $\sim 60 \mathrm{~m}$, and forming the main aquifer ( 100 $\mathrm{m}$ thickness) near surface to the north of the study area. TEM-3 and TEM-4 sites were found to be potential sites for groundwater artificial recharge based on the constructed hydro-geophysical model. This study recommends implementing detailed geophysical investigations particularly in the most northern parts of the study area.
\end{abstract}

\section{Keywords}

Time Domain Electromagnetic (TDEM), Groundwater Artificial Recharge, Hydro-Geophysics

\footnotetext{
"Corresponding author.
}

How to cite this paper: Al-Amoush, H., et al. (2015) Geophysical Investigation Using Time Domain Electromagnetic Method (TDEM) at Wadi Deir Al-Kahaf Area/Jordan for Groundwater Artificial Recharge Purposes. Journal of Water Resource and Protection, 7, 143-151. http://dx.doi.org/10.4236/jwarp.2015.73012 


\section{Introduction}

Time-Domain electromagnetic resistivity soundings are being increasingly used in environmentally and groundwater surveys [1]-[3]. TEM surveys were used to map the buried quaternary valleys [4] [5], for hydro-geophysical applications [6]-[8] and were used for geological mapping [9]. In the field, TEM measurements are conducted with ungrounded square or circular loops lying on the ground surface, in this configuration short DC-Pulses are introduced by the transmitter loop, which is turned off after a specified time-on period. The time it takes for the current to return to zero after being turned off mainly depends on the loop size [10]. The depth of investigation is directly proportional to the shut-off time, the recording time interval and the loop size [11]. When the transmitter loop is turned off, the primary field is rapidly decaying; eddy currents are generated in conductive material below the loop, and the decaying currents induce new electromagnetic field (secondary EM-Field) which causes a new current at even greater depths [1]. In Electromagnetic surveys, the total sum of the fields is measured. According to Maxwell's equations, the observed difference between the transmitted (primary) EM-field and the received (secondary) EM-field provides information about the nature and electrical properties of the subsurface conductive body [12].

In this study, the Time domain electromagnetic method was used in order to achieve the following objectives: (a) to investigate the subsurface deposits in terms of their types, thicknesses and layering sequences as well as their lateral and vertical extensions; (b) to create a 2D hydro-geophysical model along the study area to investigate the potential of subsurface deposits for groundwater artificial recharge.

\section{Description of the Study Area}

The study area is located in the northeastern part of Jordan (Figure 1) within the following coordinates [325,000 $329,000]$ E, [147,000 - 152,000] N according to Palestine Grid coordinate system. Elevation is ranging from 500 masl in the most southern part at Al-Azraq Al-shamali town to 640 masl in the most northeastern part of the study area. The area is classified as an arid to semi-arid area. The annual rainfall is low and reaches at maximum to $120 \mathrm{~mm}$ in the northern part and decrease gradually to south [13].

\section{Geology and Hydrogeology}

The Study area is forming the northern part of Azraq town; Azraq basin is forming a part of limestone plateau in eastern Jordan. The northeastern half of the basin is dominated by basaltic lava originating from Miocene/Oligocene volcanic activity [14]. During the Neogene, the first lava flows occurred as a result of volcanic eruptions

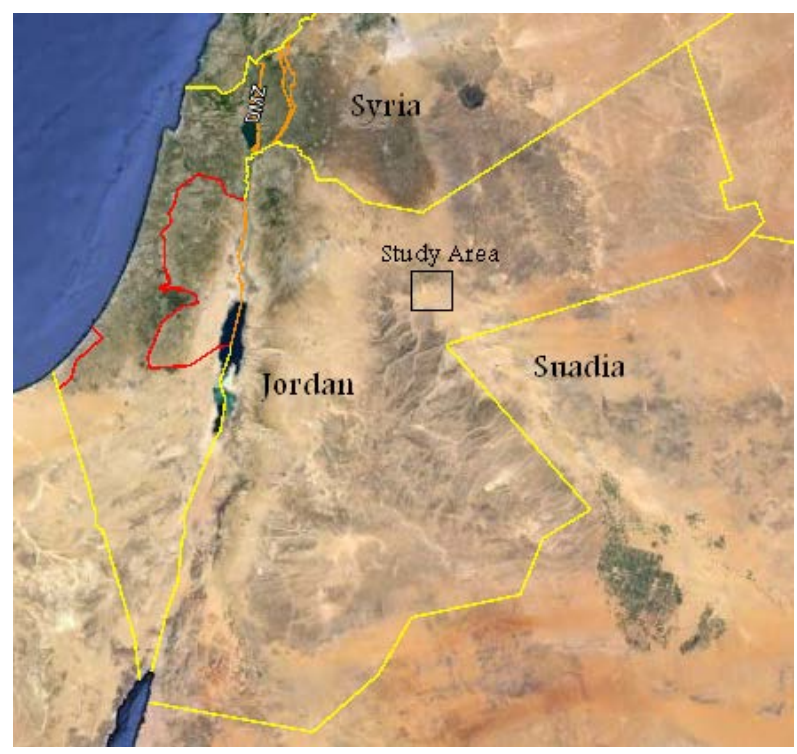

Figure 1. Location map of Jordan including the study area (enclosed rectangle) (Google earth 2014). 
where this activity continued until the Holocene. The basalt reaches a thickness of more than $1500 \mathrm{~m}$ in the area of Mount Arab in Syria, and becomes progressively thinner towards the south. Table 1 lists the sequence of Hydrogeological layers in Azraq area. The basin incorporates exposures of sedimentary rocks and basalt, ranging in age from Cretaceous to Quaternary. In the southern part of the basin and on the surface, the Quaternary deposits and recent sediments cover the underlying Tertiary deposits. The latter are intermittently exposed at the surface in the south, southwest, and southeast. Eocene and top Tertiary sediments lie on the top of the sequence [13]. The sedimentary sequence includes limestone, chert, marl, chalk, sandstone, clay, and evaporates. These rocks are frequently covered with a variably thick sequence of superficial deposits including alluvium, mud-silt flats, chert pavement, Pleistocene gravels, and sand and evaporate incrustations. To the north and northeast, basalt eruptions of different age appear on the surface and extend northwards to cover a wide surface area known as the "Basalt Plateau". This basalt area is related to the North Arabian Volcanic Province, which extends from Syria across Jordan into Saudi Arabia, covering in Jordan a surface area of $11,000 \mathrm{~km}^{2}$. In the Azraq playa (wetland reserve) the basalt is missing. Upper Tertiary sediments of (Wadi Shallala Formation-B5) are located in the structural depression zones. This Formation consists of Marly-Clayey layers in the area of Azraq well field and acts here as an aquitard between the (Umm Rijam Formation-B4) and the Basalt aquifer. Towards the southeast, B5 Formation contains more sandy layers and it is classified as an aquifer in this area. South of the basalt areas the landscape is dominated by Paleocene and Eocene Marly limestone, chalks, and chalky limestone with chert layers of the B4 formation. The B4 formation is underlain by Muwaqqar formation-B3 of Maastrichtian age. B3 formation reaches thickness of about $300 \mathrm{~m}$ and consists of marl and marly limestone with some gypsum and evaporates (Table 1) [14].

\subsection{Wadi Deir Al-Kahaf Geological Outcrops}

The main lithological outcrop in the area of study is Abed Olivine Basalt (AOB) that belongs to late Miocene of Safawi group. It was generated from feeder dyke systems and represents the earliest and most abundant volcanism in the study area [15]. It comprises massive flow of $10 \mathrm{~m}$ thick with continued thickness up to $100 \mathrm{~m}$, the basalt rock is characterized by dark to medium grey crystalline, medium to fine grained porpherytic texture, at exposures it shows vesicular mostly restricted to rounded clots, pipes and cylindrical forms [15] (Figure 2).

The present day drainage sediments is flooded by stony or boulder deposits and unsorted gravel of basalt, sand and silt derived from various lithological units, which forms the alluvium and Wadi sediments up to $20 \mathrm{~m}$ thickness. Water accumulates during floods times and fine silts and clays are deposits to form mudflats or silt flats [15] (Figure 2).

\subsection{Basalt Aquifer (Abed Olivine Basalt; AOB)}

This aquifer covers the northern part of the Azraq Basin, extending from Jebel Druze Mountains in Syria to Azraq. The basalt aquifer consists of alkali olivine lava flows intercalated by the layers of red clay. This lava flows of Tertiary to Quaternary deposits overly unconformably the sedimentary successions of the Belqa Group (B4/B5). Five lava flows have been identified by [16] in the Azraq Basin. The basalts are hydraulically connected with the underlying Shallala (B5) Aquifer, and the Umm Rijam (B4) Aquifer. These basalt aquifers in the Azraq Basin tend to be productive and good aquifer due to high fracturing of the basalts "saturated basalts" (Table 1).

Table 1. Major units of the shallow aquifer in the Azraq basin area [17]*.

\begin{tabular}{|c|c|c|c|c|}
\hline Hydraulic Character & Thickness (m) & Lithology & Formation & Age \\
\hline Aquifer & $0-20$ & Sands and gravel & Alluvium & Recent Quaternary \\
\hline Aquifer & $0-400$ & Basalt & Basalt & L. Tertiary \\
\hline Aquifer & $0-15$ & Weathered limestone & Um Qirma (B5) & L. Eocene \\
\hline Aquiclude & $160-430$ & Marl and Chalk & Wadi el Shallala (B5) & L. Eocene \\
\hline Aquifer & $170-300$ & Argillaceous silicified limestone & Umm Rijam (B4) & Mid-Eocene \\
\hline Aquiclude & $>100$ & Marly limestone & Muwaqqar (B3) & E. Eocene \\
\hline
\end{tabular}

${ }^{*}$ At the study area the Aquifer System is an unconfined aquifer. The aquifer consists essentially of three different members partly separated from each other and partially directly connected. These are Quaternary sediments (Alm), Basalt (AOB), Umm Rijam (B4), and Shallala (B5). 


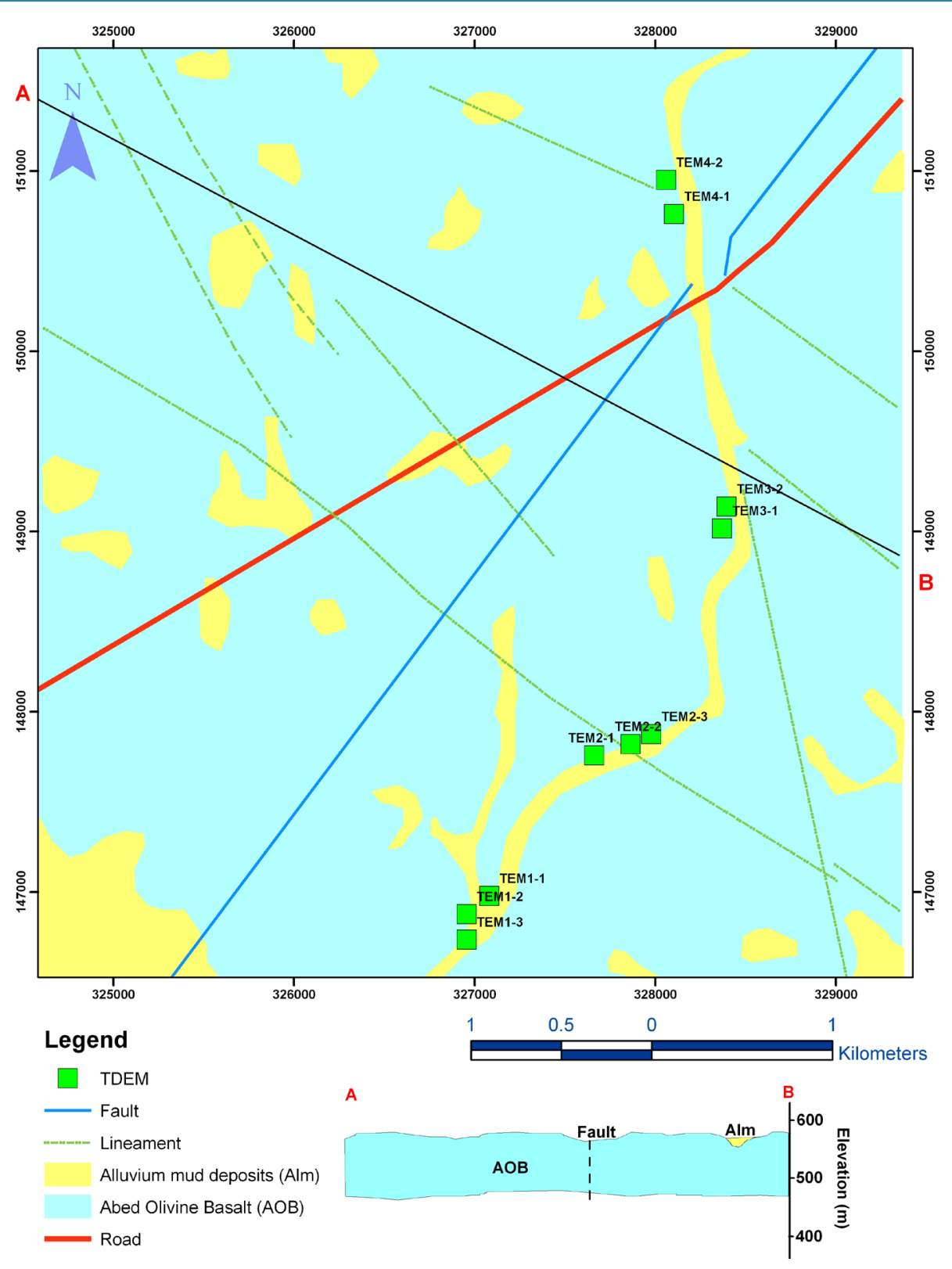

Figure 2. Geological map (modified after [13], geological cross section, and TEM loop locations at the study area).

\subsection{Wadi Shallala Aquifer (B5)}

Shallala Formation (B5) which underlies the basalt consists of marl, clay and marly limestone and acts as an aquifer between the two good aquifers, the B4 and the Basalt Aquifer. The thickness of the B5 in basaltic area reaches about $70 \mathrm{~m}$. The B5 is unconfined aquifer and hydraulically connected with the underlying B4 Aquifer. It's thickness increase eastward towards the Fuluk Fault from 160 to 428 m [17] (Table 1).

\subsection{Umm Rijam Aquifer (B4)}

This aquifer underlies the Shallala Formation; it consists of white limestone, chalky limestone, and nodules of brown to black chert. The Umm Rijam Formation outcrops in the central, southern and western part of the basin. The average thickness of the B4 Formation is about $60 \mathrm{~m}$. From the general hydrogeology of the Azraq Basin, it appears that, the B4 Aquifer is hydraulically connected with the Basalt Aquifer via Shallala (B5) [17]. 


\subsection{Structure}

Structurally, the area is tectonically dominated with NW-SE, E-W, NESW and N-S faults and lineaments; the NW-SE and the EW fault systems are the main ones believed to have controlled the development of the Azraq depression and Azraq Lake [13]. The regional dip is towards northeast. Folds are relatively small with gentle dip and mainly associated with some NE faults and lineaments. The geology of the Azraq Basin is controlled by the relative northeastern movement of the Arabian Plate with respect to the African Plate. There are two major fault systems in the Azraq Basin one trending E-W and a second, NW-SE. A Graben trending NW-SE is the dominant structure [13]. The Jabal Fuluk Fault which stretches from the Basalt is the main Fault in the northern part of this Graben. Some Faults are extending NW-SE parallel to the Graben, and others have a NWW-SSE strike. The basin is characterized by the presence of distinctive structures including the Sirhan-Fuluk Siwaqa, Zarqa Main, and Baqal-Wisad fault systems [13].

\section{Data Acquisition and Modeling}

Different maps such as (geology, structure, lithology, Roads, TDEM measuring sites) were gathered, digitized, geo-referenced according to local coordinates system (Palestine Grid system) and incorporated into GIS environment and forming the basis for further subsequent processing.

Time Domain Electromagnetic (TDEM) measurements were carried out in a detailed survey location regarding to the Wadi Deir Al-Kahaf area and divided into four sites namely: Location 1: TEM 1-1, TEM 1-2, TEM 1-3, Location 2: TEM 2-1, TEM 2-2, TEM 2-3, Location 3: TEM 3-1, TEM 3-2, and Location 4: TEM 4-1, TEM 4-2. The locations and coordinates of TEM's measurements are shown in (Figure 2 and Table 2) respectively. The optimum site selection was adopted such that the spatial distribution of TEM data are mostly sampled the study area and nearby locations.

In this study, Ten Time Domain Electromagnetic (TDEM) loops at four selected sites along Wadi Deir AlKahaf course were performed, in which coincident single turn of $50 \mathrm{~m} \times 50 \mathrm{~m}$ loop was used to gain sufficient penetration depth $(\sim 100 \mathrm{~m})$. The system was set to transmit current up to 4 Ampere using 12 Voltage source batteries with 48 active time gates $(15,360 \mu \mathrm{s}-\mathrm{t}$ center). The stacking time was set to about 5 minutes with 50 $\mathrm{Hz}$ noise filter in order to avoid aliasing effects of possible galvanic interference. TDEM measurements were gathered using the TEM-FAST 48HPC which comprising a Transmitter-Receiver controller and managed by HP-IPAQ pocket system [18]. Data processing and inversion were done using the associated software TEMRESEARCHER [19] which allowing generation of pseudo- and inverse Resistivity sections and maps from 1-D sounding Resistivity. Figure 3 shows an example of inversion at location-1. The Multilayer best fit interpretation of TEM's measurements is present in Table 3.

Table 2. Coordinates of TDEM loops at the study area.

\begin{tabular}{cccccccc}
\hline Location & TEM ID & Easting (UTM) & Northing (UTM) & PGN (m) & PGE (m) & Elevation (masl) \\
\hline \multirow{2}{*}{ Location-1 } & TEM1-1 & 36.868750 & 31.906050 & 147,099 & 326,899 & 510 \\
& TEM1-2 & 36.867417 & 31.905167 & 146,999 & 326,774 & 510 \\
& TEM1-3 & 36.867383 & 31.903883 & 146,857 & 326,773 & 511 \\
Location-2 & TEM2-1 & 36.876950 & 31.913283 & 147,913 & 327,662 & 527 \\
& TEM2-2 & 36.879083 & 31.913817 & 147,975 & 327,863 & 526 \\
Location-3 & TEM2-3 & 36.880300 & 31.914300 & 148,031 & 327,978 & 527 \\
& TEM3-1 & 36.883300 & 31.923150 & 149,017 & 328,246 & 537 \\
Location-4 & TEM3-2 & 36.883583 & 31.924233 & 149,137 & 328,271 & 530 \\
& TEM4-1 & 36.880783 & 31.938900 & 150,760 & 327,981 & 539 \\
\hline
\end{tabular}


Table 3. Multilayer best-fit Interpretation models of TEM measurements based on available surface geological data and geological cross sections.

\begin{tabular}{|c|c|c|c|c|}
\hline Lo. & TEM ID & Resistivity (ohm-m) & Thickness (m) & Suggested geological interpretation (Lithology/Formation) \\
\hline \multirow{17}{*}{ 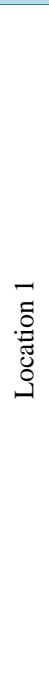 } & \multirow{5}{*}{ TEM 1-1 } & 12.5 & 5.6 & \multirow{3}{*}{ Low resistivity zone, composed of AOB saturated, and clay } \\
\hline & & 4.3 & 10.3 & \\
\hline & & 9.6 & 15.4 & \\
\hline & & 2000 & 78.2 & high resistivity zone composed of unsaturated $\mathrm{AOB}$ \\
\hline & & 0.1 & 40 & B5/B4, likely B4 with Saline water bearing layers \\
\hline & \multirow{6}{*}{ TEM 1-2 } & 14.4 & 6.35 & Alm (Alluvium mudflat, wet top soil) \\
\hline & & 4.6 & 10.6 & \multirow{2}{*}{ Low resistivity zone, composed of AOB saturated, and clay } \\
\hline & & 8.7 & 18.1 & \\
\hline & & 155 & 28.2 & AOB saturated (could be low salinity bearing layers) \\
\hline & & 2000 & 63.5 & high resistivity zone composed of unsaturated $\mathrm{AOB}$ \\
\hline & & 0.1 & 40 & B5/B4, likely B4 with Saline water bearing layers \\
\hline & \multirow{6}{*}{ TEM 1-3 } & 18.9 & 6.3 & Alm (Alluvium mudflat) \\
\hline & & 5 & 9.4 & AOB saturated/with clay (low resistivity zone) \\
\hline & & 9.3 & 19.6 & AOB/clay (fractured with clay) \\
\hline & & 76 & 34 & AOB saturated (could be low salinity bearing layers) \\
\hline & & 2000 & 65 & high resistivity zone composed of unsaturated $\mathrm{AOB}$ \\
\hline & & 0.2 & 40 & B5/B4, likely B4 with Saline water bearing layers \\
\hline \multirow{10}{*}{ 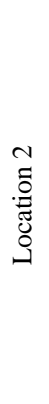 } & \multirow{5}{*}{ TEM 2-1 } & 20.5 & 9.9 & Alm (Alluvium mudflat) \\
\hline & & 7 & 11 & \multirow{4}{*}{$\begin{array}{l}\text { Low to intermediate resistivity zone, composed of AOB } \\
\text { with varying degree of saturation, porosity, and clayey conten }\end{array}$} \\
\hline & & 33 & 31 & \\
\hline & & 7.6 & 10 & \\
\hline & & 14.5 & 10 & \\
\hline & \multirow{5}{*}{ TEM 2-2 } & 21.7 & 9.8 & Alm (Alluvium mudflat) \\
\hline & & 6.5 & 12 & Low resistivity zone, composed of AOB \\
\hline & & 11.7 & 4 & with varying degree of clayey content, and porosity values \\
\hline & & 50.7 & 48.1 & \multirow{2}{*}{$\begin{array}{l}\text { intermediate resistivity layer, composed of AOB with higher } \\
\text { degree of saturation and less clayey content content }\end{array}$} \\
\hline & & 84.6 & 28.4 & \\
\hline \multirow{13}{*}{ 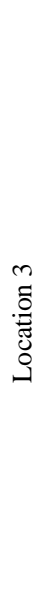 } & \multirow{5}{*}{ TEM 2-3 } & 48.8 & 15 & Alm (Alluvium mudflat, wet top soil) \\
\hline & & 8 & 11 & $\begin{array}{l}\text { Low resistivity zone, composed of AOB with clay with } \\
\text { varying Degree of clayey content, and porosity }\end{array}$ \\
\hline & & 15.9 & 4 & intermediate resistivity layer, composed of AOB \\
\hline & & 33.2 & 39.9 & with highly degree of saturation and less clayey content \\
\hline & & 24 & 5 & B4? \\
\hline & \multirow{5}{*}{ TEM 3-1 } & 48.3 & 20.6 & Alm/AOB/wet top soil/clay \\
\hline & & 14 & 12 & AOB saturated/with clay \\
\hline & & 46.4 & 26.4 & intermediate resistivity layer, composed of AOB \\
\hline & & 19.1 & 52.4 & with varying degrees of saturation clayey content \\
\hline & & 104 & 55 & AOB saturated \\
\hline & \multirow{4}{*}{ TEM 3-2 } & 68.7 & 22.5 & Alm/AOB saturated/ with clay \\
\hline & & 2000 & 5 & high resistivity zone composed of unsaturated $\mathrm{AOB}$ \\
\hline & & 19 & 67 & $\begin{array}{l}\text { intermediate resistivity layer, composed of AOB } \\
\text { with varying degrees of saturation clayey content }\end{array}$ \\
\hline \multirow{10}{*}{ 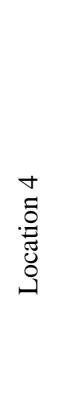 } & & 516 & 41 & B4? \\
\hline & \multirow{4}{*}{ TEM 4-1 } & 35.1 & 10 & Alm (Alluvium mudflat) \\
\hline & & 82.1 & 6.5 & \multirow{2}{*}{$\begin{array}{l}\text { intermediate resistivity layer, composed of AOB } \\
\text { with lower degree of saturation }\end{array}$} \\
\hline & & 68.7 & 19.6 & \\
\hline & & 48 & 51 & \multirow{2}{*}{$\begin{array}{l}\text { intermediate resistivity layer, composed of AOB saturated } \\
\text { Alm/AOB/wet top soil /clay }\end{array}$} \\
\hline & \multirow{5}{*}{ TEM 4-2 } & 95.5 & 26 & \\
\hline & & 2000 & 5.4 & \multirow{2}{*}{$\begin{array}{l}\text { high resistivity zone composed of unsaturated AOB } \\
\text { resistivity zone composed of unsaturated AOB }\end{array}$} \\
\hline & & 148.9 & 7.4 & \\
\hline & & 45 & 21 & intermediate resistivity layer, composed of saturated AOB \\
\hline & & 61.4 & 26.7 & with highly degree of saturation and less clayey content \\
\hline
\end{tabular}



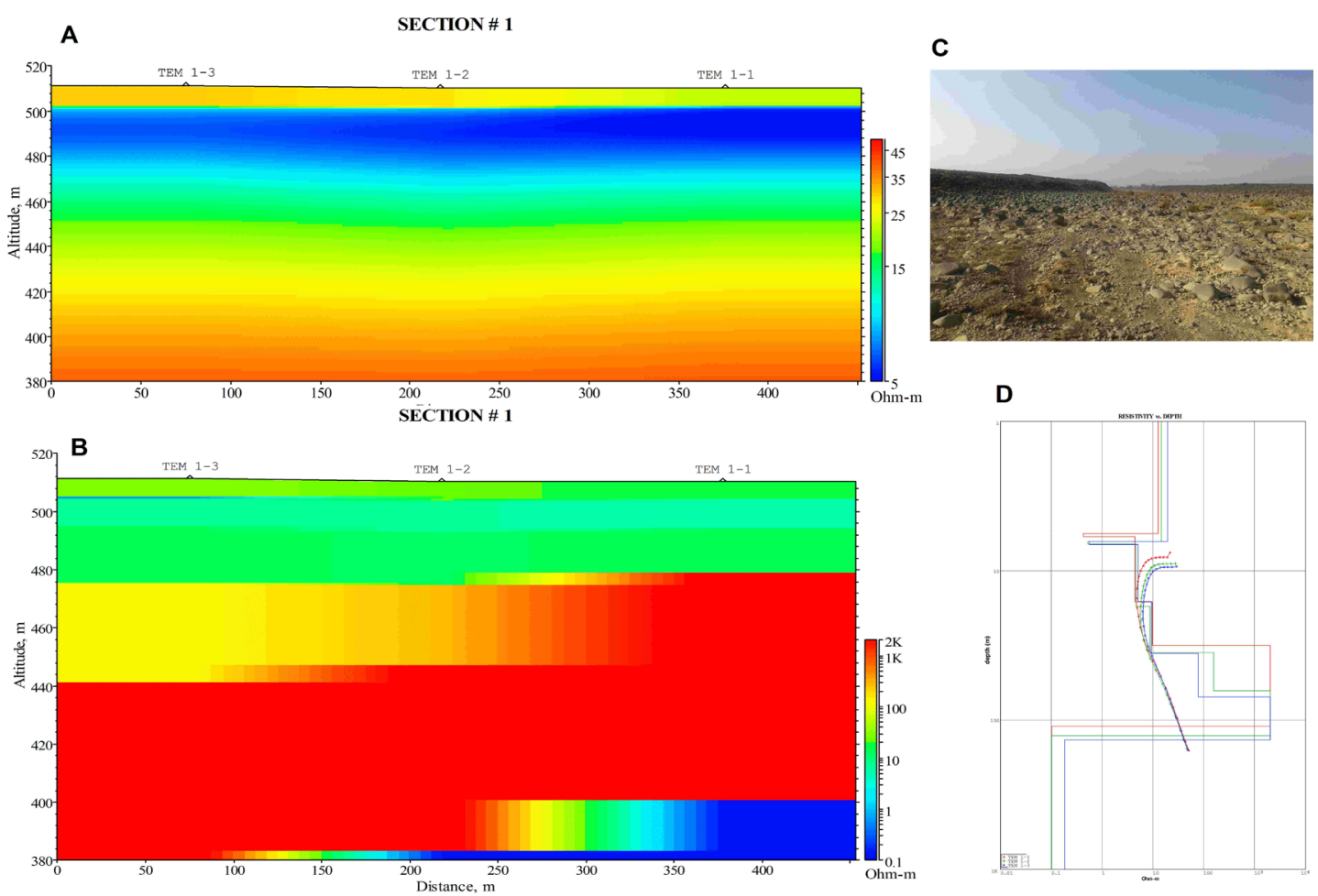

Figure 3. Interpretation of resistivity data at location 1 (a) TEM apparent resistivity pseudo-section; (b) TEM resistivity model cross section; (c) Site photograph; (d) Resistivity data log.

\section{Results, Discussion and Conclusion}

In this study a hydro-geophysical cross section along the study area has been constructed using the geological information and the results of TDEM's modeling results and presented in Figure 5 to assess the hydro-geological conditions and litho-logical properties of the Wadi Deir Al-kahaf area. Figure 4 shows a schematic geological cross section through Azraq area and illustrates the subsurface hydrogeological conditions along the study area. The TEM results suggest well resolved geological layers such as Aluvium mud flat (Alm), Abed Olivine Basalt (AOB) (saturated, partially saturated and unsaturated geological layers depending on clay intercalation and porosity), and a mixture of rocks at near surface of the main investigated areas (Figure 5). A significant faultinterpreted as a lineament extracted from aerial photograph (Figure 2) is found between TEM 2-1 and TEM 2-2 and the interpreted fault might be responsible for resolving deep geological formation; Umm Rijam Formation (B4) that is saturated with saline water coming from southern hyper-saline mudflat deposits at al Qa' area and terminates at the area of TEM 1-1, TEM 1-2, and TEM 1-3 sites. Other explanation is related to Wadi El Shallala Formation (B5) rather than B4 where $0.1 \mathrm{ohm}-\mathrm{m}$ formation resistivity is basically related to chalky marl rocks saturated with saline water (B5). Additionally, the hydro-geological features extracted from the integration of all TEM sites reveal a substantial increasing in saturated AOB aquifer to the north direction (i.e. toward site TEM 3 and TEM 4 sites). Furthermore, depending on the hydro-geophysical section (Figure 5) it was possible to locate lateral changes in rocks properties due to water saturation and or facies changes (i.e. clay intercalation); these subsurface changes are clear even at small horizontal scale (i.e. marked as zigzag dashed line on Figure 5) which is believed to be related to specific rock types having hydro-geological properties that render them susceptible to form this structure.

The saturated thickness of the Upper Aquifer System in the study area varies from one site to another predominantly, regarding the variations in the hydraulic properties of the different layers (i.e. $5 \mathrm{~m}$ thickness near TEM 1 to about $120 \mathrm{~m}$ thickness near TEM 4). The Abed Basalt Aquifer (AOB) has an average saturation thickness of about $\sim 60 \mathrm{~m}$ (Figure 5 and Table 2 ) and forms the main aquifer ( $\sim 100 \mathrm{~m}$ thickness) near surface to the north of the study area, see geological cross section in Figure 1.

Apparently, Umm Rijam Formation (B4) which is expected to underlain the basalt specifically at TEM 1-1, 


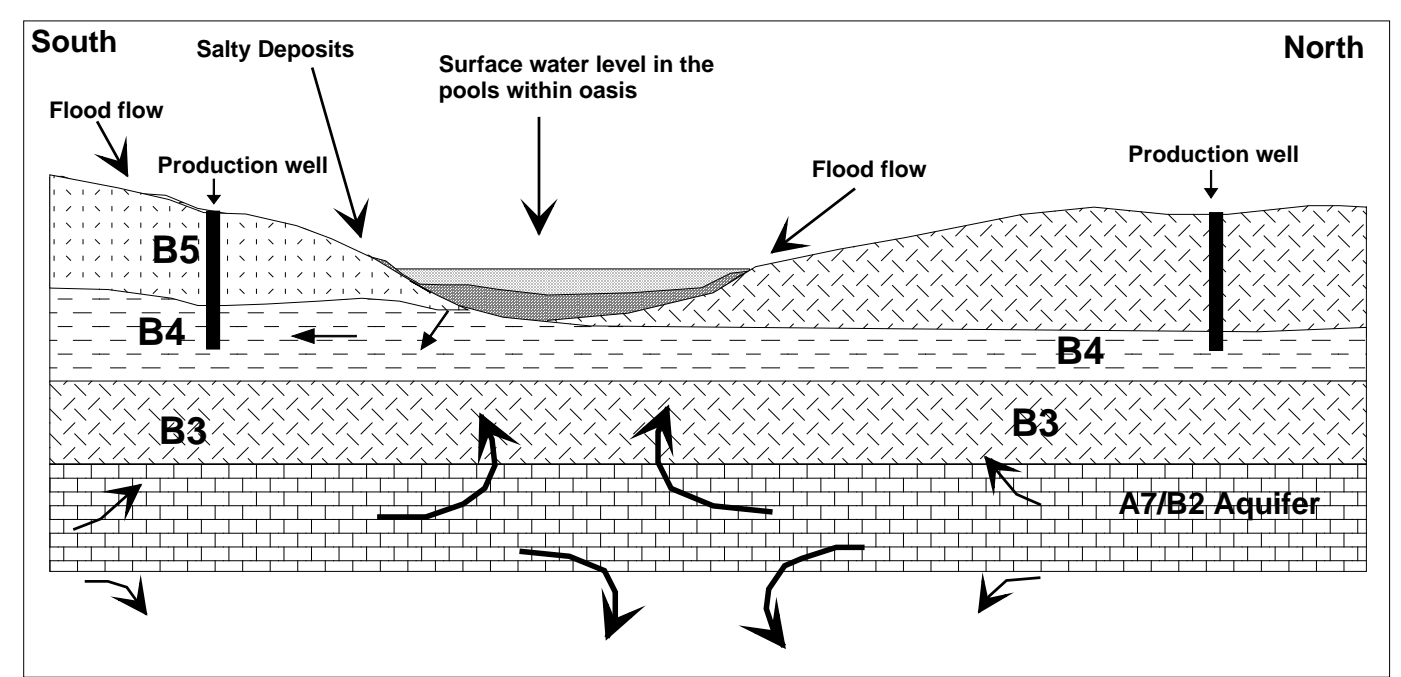

Figure 4. Schematic geological cross-sections through the Azraq area reveal subsurface hydrogeological condition along the study area, modified after [20] and [21].

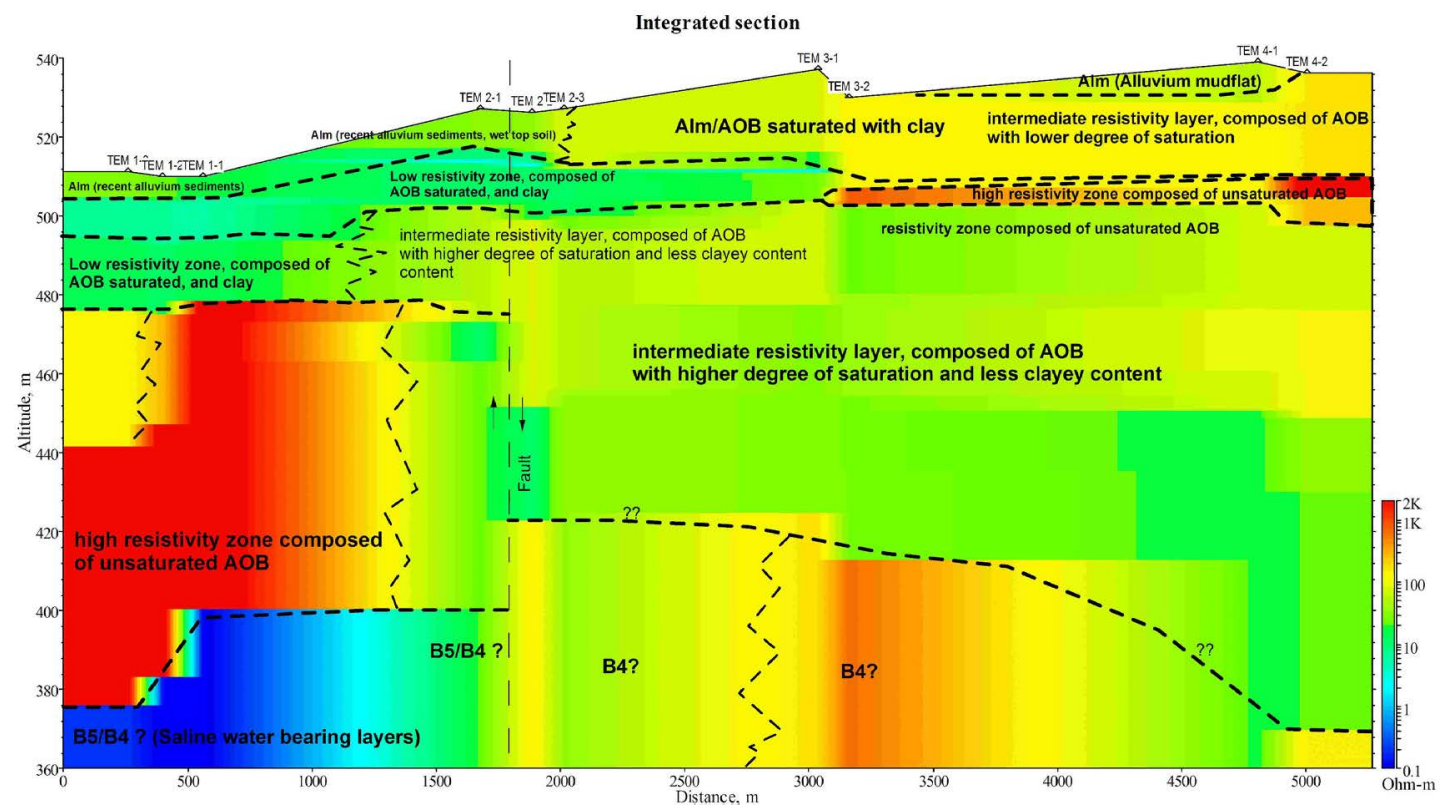

Figure 5. Hydro-geophysical resistivity model section based on the integration of ten TEM results, geological map, and geological cross section at Wadi Deir Al-Kahaf area.

TEM 1-2 and TEM 1-3 sites, acts as saline aquifer in the Basalt area, where the overlying basalts are unsaturated. Consequently umm Rijam fault B4 consisting basically of chert and limestone appears to be also saturated (very low resistivity due to hyper-saline groundwater). Moreover, it changes in petrophysical properties (i.e. saturated or partially saturated) (Figure 4) where the overlying basalts are saturated (Figure 5) (hence, near TEM 3 and TEM 4 sites) (Figure 5).

\section{References}

[1] Hoekstra, P. and Blohm, M.W. (1990) Case Histories of Time-Domain Electromagnetic Soundings in Environmental Geophysics. In: Ward, S.H., Ed., Geotechnical and Environmental Geophysics, II, Society of Exploration Geophysicists, Tulsa, 1-15.

[2] McNeill, J.D. (1990) Use of Electromagnetic Methods for Groundwater Studies. In: Ward, S.H., Ed., Geotechnical and 
Environmental Geophysics 01, Society of Exploration Geophysicists, Tulsa, 191-218.

[3] Auken, E., Jorgensen, F. and Sorensen, K.I. (2003) Large-Scale TEM Investigation for Ground-Water. Exploration Geophysics, 33, 188-194. http://dx.doi.org/10.1071/EG03188

[4] Jorgensen, F., Sandersen, P.B. and Auken, F. (2003) Imaging Buried Quaternary Valleys Using the Transient Electromagnetic Method. Journal of Applied Geophysics, 53, 199-213. http://dx.doi.org/10.1016/j.jappgeo.2003.08.016

[5] Jorgensen, F., Lykke-Andersen, H., Sandersen, P.B.E., Auken, E. and Normark, E. (2003) Geophysical Investigations of Buried Quaternary Valleys in Denmark: An Integrated Application of Transient Electromagnetic Soundings, Reflection Seismic Surveys and Exploratory Drillings. Journal of Applied Geophysics, 53, 215-228. http://dx.doi.org/10.1016/j.jappgeo.2003.08.017

[6] Christensen, N.B. and Sorensen, K.I. (1998) Surface and Borehole Electric and Electromagnetic Methods for HydroGeophysical Investigations. European Journal of Environmental and Engineering Geophysics, 3, 75-90.

[7] Danielsen, J.E., Auken, E., Jorgensen, F., Sondergaard, V.H. and Sorensen, K.I. (2003) The Application of the Transient Electromagnetic Method in Hydrogeophysical Surveys. Journal of Applied Geophysics, 53, 181-198. http://dx.doi.org/10.1016/j.jappgeo.2003.08.004

[8] Poulsen, L.H. and Christensen, N.B. (1999) Hydrogeophysical Mapping with the Transient Electromagnetic Sounding Method. European Journal of Environmental and Engineering Geophysics, 3, 201-220.

[9] Jorgensen, F., Sandersen, P.B.E., Auken, E., Lykke-Andersen, H. and Sorensen, K. (2005) Contributions to the Geological Mapping of Mors, Denmark-A Study Based on a Large-Scale TEM Survey. Bulletin of the Geological Society of Denmark, 52, 53-75.

[10] Pellerin, L., Labson, V. and Pfeifer, C. (1994) VETEM-A Very Early Time Electromagnetic System. Proceedings of the Symposium on the Application of Geophysics to Engineering and Environmental Problems, SAGEEP, Boston, 795802.

[11] Spies, B.R. (1989) Depth of Investigation in Electromagnetic Sounding Methods. Geophysics, 54, 872-888. http://dx.doi.org/10.1190/1.1442716

[12] Oghenekohwo, F.O. (2008) A Comparison of Resistivity and Electromagnetic as Geophysical Techniques. Diploma Thesis Report, African Institute of Mathematical sciences AIMS, University of Cape Town, South Africa, 27.

[13] Natural Resources Authority (NRA) Open Files, Jordan. (2008). www.nra.gov.jo

[14] Bender, F. (1974) Geology of Jordan. Gebrueder Borntraeger, Berlin, 196 p.

[15] Ibrahim, K. (1996) The Regional Geology of Al Azraq Area. Hashemite Kingdom of Jordan, Geological Mapping Division. Natural Resources Authority, Bulletin 36.

[16] Al-Dmour, T.M. (1992) Interpreting the Geology of Azraq, South Area of Jordan, Using Landsat TM Data. Geology Directorate, Natural Resources Authority, Jordan.

[17] Gibbs, B. (1993) The Hydrogeology of Azraq Basin, N.E. Badia. MSc Thesis, University College London, London.

[18] Barsukov, P.O., Fainberg, E.B. and Khabensky, E.O. (2007) Shallow Investigation by TEM-FAST Technique: Methodology and Case Histories. In: Spichak, V.V., Ed., Methods of Geochemistry and Geophysics, Elsevier, Amsterdam, 55-77.

[19] TEM-Researcher Software, Applied Electromagnetic Research (AEMR). 2007, Netherlands.

[20] Salameh, E. (1996) Water Quality Degradation in Jordan. 1st Edition, Friedrich Elbert Stifing (FES) and Royal Society for Conservation of Nature (RSCN), Amman.

[21] IUCN (2010) Study of Salt Water Intrusion in the Upper Aquifer in Azraq Basin. Unpublished Final Report. 
Scientific Research Publishing (SCIRP) is one of the largest Open Access journal publishers. It is currently publishing more than 200 open access, online, peer-reviewed journals covering a wide range of academic disciplines. SCIRP serves the worldwide academic communities and contributes to the progress and application of science with its publication.

Other selected journals from SCIRP are listed as below. Submit your manuscript to us via either submit@scirp.org or Online Submission Portal.
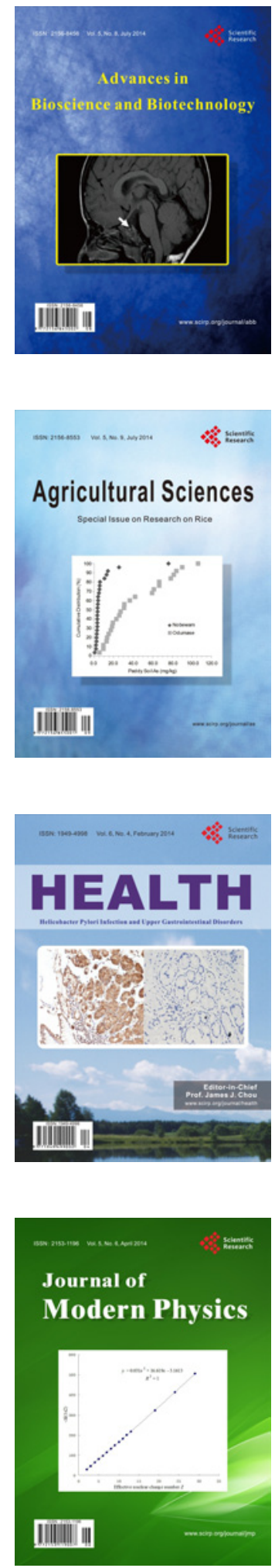
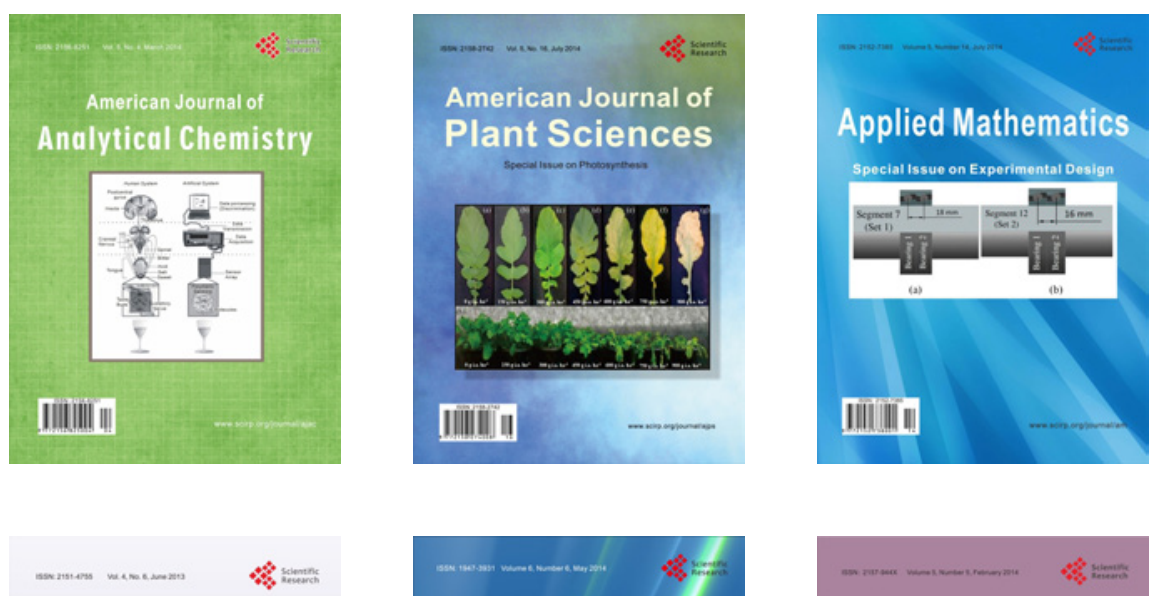

Creative Education
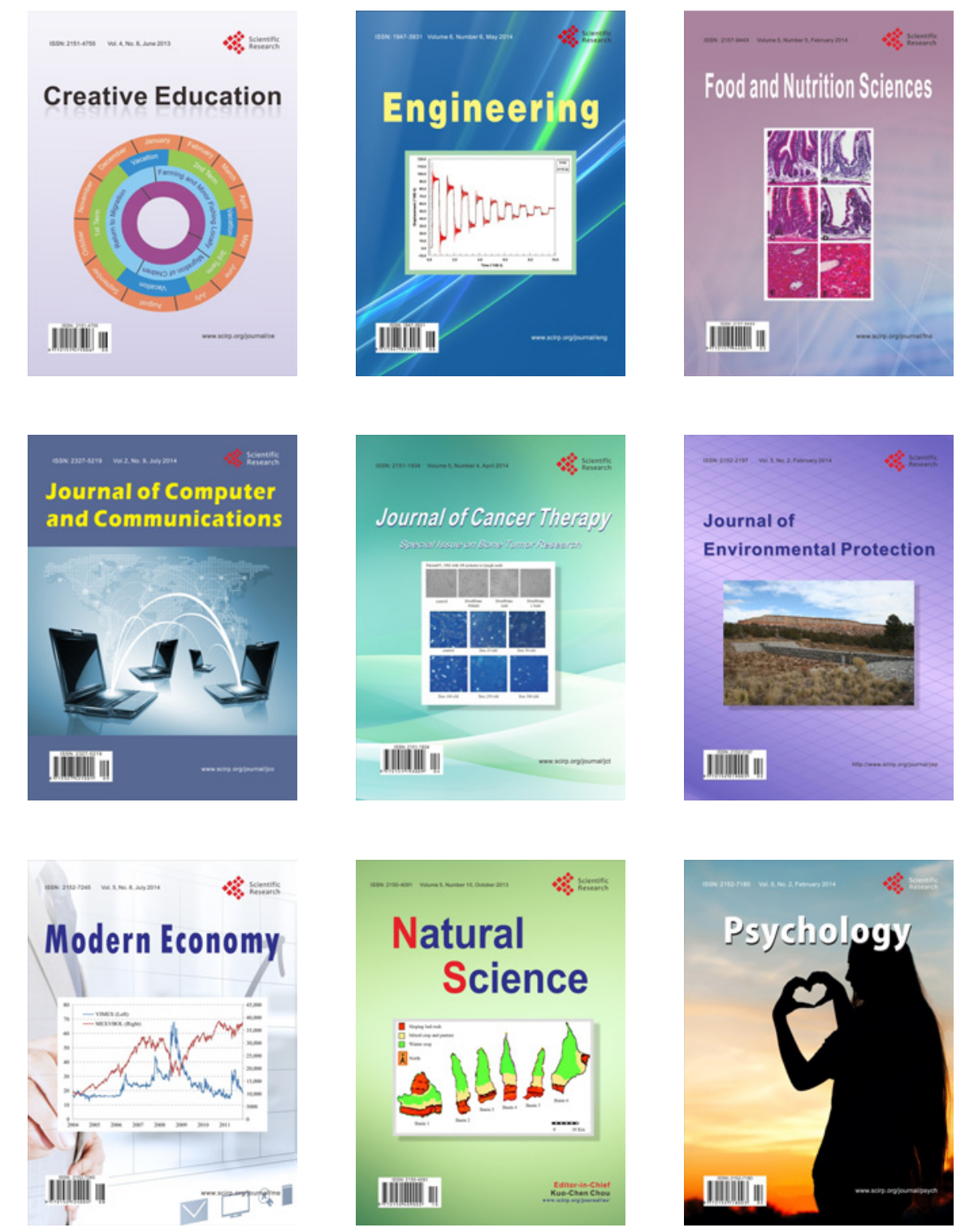